\title{
Quercetin: a natural compound for ovarian cancer treatment
}

\author{
Rana Shafabakhsh and Zatollah Asemi*
}

\begin{abstract}
Ovarian cancer is the main cause of death among all reproductive cancers in females. In 2018, ovarian cancer was the seventh most common cancer of women entire the world. A wide variety of molecular and genetic alterations as well as different response to therapies in the different types of ovarian cancer lead to problems in design a common therapeutic strategy. Besides, ovarian cancer cells have tendency to acquire resistance to common cancer treatments through multiple mechanisms. Various factors, including cytokines, growth factors, proteases, adhesion molecules, coagulation factors, hormones and apoptotic agents have been examined to find effective cancer treatment. Phytochemicals have been indicated to have great potential anti-cancer properties against various types of cancers. Quercetin is one of the phytochemicals that exists extensively in daily foods. Wide evidences revealed that quercetin is able to inhibit various types of cancers including breast, lung, nasopharyngeal, kidney, colorectal, prostate, pancreatic, and ovarian cancer. Several in vitro and in vivo studied conducted to evaluate cytotoxic effects of quercetin on ovarian cancer. Since quercetin does not harm healthy cells and it is cytotoxic to cancer cells via various mechanisms, researchers suggest that it could be an ideal agent for ovarian cancer treatment or an adjuvant agent in combination with other anti-cancer drugs. Thus, in this review, we focused on chemo-preventive and curative attitude of quercetin for ovarian cancer and summarize some of the most recent findings which regard the possible molecular mechanisms by which this natural compound inhibits this cancer.
\end{abstract}

Keywords: Ovarian cancer, Quercetin, Genetic alterations

\section{Introduction}

Ovarian cancer is the most fetal of all reproductive cancers, the eleventh most common type, and the fifth main cause of cancer-associated death in women. In 2018, ovarian cancer was the seventh most frequent cancer of females globally, with about 240.000 new subjects [1]. Ovarian cancer is commonly not diagnosed until advanced stages because of its silent and obscure symptoms which make it hard to cure appropriately [2]. In spite of widespread awareness of this cancer in these years, its survival rate has not significantly changed due to difficulties existing in its early diagnosis [3]. Some common symptoms of ovarian cancer are including abdominal pain, abdominal bloating, urinary frequency and changes in bowel habits [2, 4]. It is essential for health care supporters to consider these vague and non-specific symptoms especially in high-risk cases. Several risk

\footnotetext{
* Correspondence: asemi_r@yahoo.com

Research Center for Biochemistry and Nutrition in Metabolic Diseases, Kashan University of Medical Sciences, Kashan, IR, Iran
}

factors, including family history or genetic predisposition, ovulation, endometriosis, dietary factors, and race has been known for this disorder [5]. Ovarian cancer divided into 3 types: epithelial (most frequent), germ cell, and sex-cord-srtomal. Epithelial ovarian cancer has four histological subtypes: serous, endometrioid, mucinous and clear cell [2]. The various molecular and genetic alterations of these types of ovarian cancer as well as their different responses to therapies lead to a challenge in design a common treatment strategy [6]. In ovarian cancer, the tumor microenvironment is consist of immune cells, fibroblasts, extracellular matrix (ECM), some enzymes such as matrix metalloproteinase (MMPs), and growth factors such as vascular endothelial growth factor (VEGF), transforming growth factor- $\beta$ (TGF- $\beta$ ), and platelet-derived growth factor (PDGF). These components promote tumor cell proliferation, migration and invasion [7].

Ovarian cancer cells are willing to establish resistance to common cancer therapies. Cancer cells are able to

(c) The Author(s). 2019 Open Access This article is distributed under the terms of the Creative Commons Attribution 4.0 International License (http://creativecommons.org/licenses/by/4.0/), which permits unrestricted use, distribution, and 
acquire drug-resistance via multiple mechanisms [8]. A large number of factors, including inflammatory cytokines, growth factors, proteases, adhesion molecules, coagulation factors, hormones, and apoptotic agents have been evaluated in order to find effective cancer treatment. Wide experimental studies have demonstrated that phytochemicals such as polyphenols, flavones and flavonoids exert great potential anti-cancer properties against various types of cancers [9].

Quercetin is one of the phytochemicals that is widely found in foods consumed daily. This polyphenol compound widely exists in nuts, teas, vegetables, herbs and generally daily diet of people [10]. Also, it is available as commercial supplement. It is safe at oral dosages of $1 \mathrm{~g} /$ day which is absorbed up to 60\% [11]. Quercetin has an extended variety of pharmacological usages such as antioxidant, anti-diabetic, anti-inflammatory and antiproliferative functions [12-14]. Quercetin, 2-(3,4-dihydroxyphenyl)-3,5,7-trihydroxy4H-chromen-4-one, is well known by its 2-hydroxyflavone backbone consisted of two benzene rings, $\mathrm{A}$ and $\mathrm{B}$, linked by a 3-carbone heterocyclic pyrone one [13]. The strong ability of quercetin in free radical scavenging and binding to transition metal ions is due to the presence of two antioxidant pharmacophores in its structure [13]. In addition, the presence of catechol and the $\mathrm{OH}$ group at position $\mathrm{C} 3$ of its structure provide a great configuration for scavenging of free radicals $[13,15]$. Quercetin is a pentalhydroxyflavonol which has 5 hydroxyl groups on its flavonol skeleton at 3, 30, 40 5, and 7 position carbons. Various biochemical and pharmacological functions of quercetin result from the substitution of its different functional groups [16]. Several investigations showed that quercetin could be present in two ways: free state or aglycone and conjugated by various molecules such as carbohydrates, lipids, alcohols, and sulfate group which produce quercetin derivatives, including quercetin glycoside, prenylated quercetin, quercetin ethers and quercetin sulfate [16]. Moreover, a large amount of research on this bioactive compound has proposed several pathways which interact to treat cancer $[17,18]$. Several evidences revealed the inhibitory effects of quercetin against wide variety types of cancers, including breast, lung, nasopharyngeal, kidney, colorectal, prostate, pancreatic, and ovarian cancer [19-22]. Previous studies have reported that consumption of quercetin-high rich vegetables was related to a decreased risk of ovarian cancer [23-25]. Likewise, consumption of fruits contains quercetin such as apples and citrus fruit juices reduce the incidence of ovarian cancer [26]. Several studies have investigated cytotoxic effects of quercetin on ovarian cancer cells both in vitro and in vivo. While quercetin do not harm healthy cells, it has been identified to be cytotoxic to cancer cells via various mechanisms suggesting to be an ideal agent for ovarian cancer treatment or an adjuvant agent in combination with other anti-cancer drugs [27]. Thus, in this review, we focused on chemo-preventive and curative attitude of quercetin for ovarian cancer and summarize some of the most recent findings which regard the possible molecular mechanisms by which this natural compound inhibits this cancer.

\section{Ovarian cancer carcinogenesis and progression: molecular mechanisms}

There are several theories about the processes by which ovarian cancer progresses. One of them is ovulation theory suggests that frequent ovulation with recurrent breakdown and repair of ovarian epithelium elevates the possibility of DNA damage and carcinogenesis [28]. Therefore, more ovulations provide higher risk of ovarian cancer development. Hyper-ovulation in rats significantly elevates the possibility of ovarian adenocarcinoma progression. Some experimental studies revealed that ovulation may lead to carsinogenesis by initiating multiple cellular events [29]. Hence, excessive ovulation increases the risk of mutagenicity which may be intervened by inflammation. Various inflammatory mediators such as prostaglandins and leukoteriens as well as vasoactive substances such as bradykinin are increased during ovulation. Follicle rupture which occurs during ovulation has also features of inflammation. Taken together, the process of ovulation is strongly associated with inflammatory reactions. Especially, epithelium located around the ovulation site, have more contacts with inflammatory mediators such as cytokines, prostaglandins and oxidative stress [30]. Another theory is gonadotrophin theory which suggests that increased levels of gonadotrophins induce epithelium proliferation within inclusion cysts directly or by the stimulation of steroidogenesis leading to neoplastic transformation [31]. Data also reported that reproductive hormones are related to ovarian cancer carcinogenesis as progestins which have pro-apoptotic actions, reduce the risk of tumor transformation while estrogen promotes malignancy [32]. Moreover, chronic inflammation has also been suggested to play potential role in ovarian cancer development [33]. Epithelial ovarian cancer cells are able to metastasize to the peritoneal cavity and lead to an accumulated ascites which provide an immunosuppressive microenvironment exacerbating tumor development. Ascetic fluid activates protein kinase B (or Akt) and prevents apoptosis induced by tumor necrosis factor receptor apoptosis-inducing ligand (TRAIL) [34]. The dynamic alteration in cytokines of ascites has been indicated in a recent study in which ascites and plasma samples of advanced epithelial ovarian cancer showed a remarkable change in cytokines and inflammatory molecules [35]. Moreover, a wide variety of inflammatory 
agents, including interleukin-6 (IL-6), Akt, lysophosphatidyl acid (LPA) and protein kinase C (PKC) have been found to be elevated in ovarian cancer [36]. LPA is identified to elevate IL-6, IL-8 and VEGF through Akt/ nuclear factor kappa B (NF-kB) pathway in ovarian cancer cells [37]. PKC also plays a vital modulatory role in a large number of signal transduction pathways of cancer. Impairment in PKC function has been observed in tumorogenesis and drug-resistance related to ovarian cancer [38]. Altogether, these mentioned agents and pathways actively enhance ovarian cancer related to inflammation. Inflammation naturally generates several toxic oxidant agents which causes directly damage of DNA, proteins, and lipids leading to carcinogenesis [39]. Additionally, chronic inflammation is related to elevated cell proliferation. Excessive and rapid cell division causes additional replication errors resulting in DNA repair and thereby may elevate mutagenesis risk [40]. Ovarian cancer cells release several inflammatory mediators, cytokines and interleukins [41]. For example, prostaglandins levels are greater in ovarian tumors than normal cells [42]. Elevated levels of prostaglandins stimulate the invasion of cancer cells [43]. Another important event which is developed during ovarian cancer is oxidative stress. Findings have reported that patients with ovarian cancer have reduced concentrations of antioxidants and greater levels of oxidative stress than healthy women [44-47]. In previous studies, it has been observed that epithelial tissues of ovarian cancer exert a pro-oxidant condition with elevated expression of pro-oxidant enzymes and reduced expression of antioxidant enzymes. Elevated expression of inducible nitric oxide synthase (iNOS), myeloperoxidase (MPO), $\mathrm{NAD}(\mathrm{P}) \mathrm{H}$ oxidase, and nitric oxide (NO) as well as lowered apoptosis have been observed in ovarian cancer tissues [45, 48, 49]. Moreover, increased nitrosylation of caspase- 3 which leads to a significant reduction in the activity of caspase- 3 was seen in ovarian tumors. MPO is an important oxidant enzyme which enhances the production of NO from iNOS [50, 51]. Many recent data reported an elevation in MPO levels of ovarian cancer cells [52]. MPO also has key roles in the regulation of apoptosis, immune surveillance mechanisms, 3-nitrotyrosine formation, and inflammatory responses [45]. Additionally, MPO as a source of free iron promotes oxidative stress through contributing to reactive oxygen species (ROS) generation. Under oxidative stress, iron reacts with hydrogen peroxide $(\mathrm{H} 2 \mathrm{O} 2)$ and thereby increases ROS production [47]. Above all, oxidative stress may play a key role in ovarian cancer maintenance and progression.

\section{Anti-cancer effects of quercetin}

Quercetin is a lipophilic compound which is able to cross the cellular membranes and initiate multiple intracellular signaling pathways implicated in chemoprevention. Several investigations have reported the potential anti-cancer effects of quercetin in wide variety types of cancers. One of the unique abilities of quercetin is its dual function as a pro-oxidant or antioxidant [53]. A ROS elevation result from oxidative stress leads to DNA damage which is promotes mutations. Mutations lead to uncontrolled growth of malignant tumor cells. Quercetin can reduce ROS by donating electrons and thereby decreased ROS-mediated DNA damage [10, 54]. This is the primary antioxidant mechanism of quercetin observed at its cellular concentrations which could be obtained by diet [55]. In contrast, quercetin increases oxidative stress and cytotoxicity at higher concentrations by elevating damage and inducing apoptotic pathways in tumor cells [10, 54]. Quercetin is also known as a great apoptosis inducer at its high concentrations. It is proved that mitochondrial-mediated pathway is the main mechanism which quercetin used for its apoptosis induction effect [56-58]. Quercetin induces apoptosis through activation of p53, elevation of proapoptotic molecules such as Bax, caspase- 3 , caspase- 9 and reduction of anti-apoptotic agents such as survivin and Bcl-2 [59]. Several experimental studies revealed that higher dosages of quercetin are also able to induce apoptosis via death-domain pathways in various cancer cells [60]. In addition, emerging data is showing that quercetin directly inhibits protein chaperons and thereby stimulates apoptosis $[61,62]$. Protein chaperons have role in protein folding and maintenance that disruption in their performance leads to cell death. Un-regulation of heat shock protein (HSP) chaperones is induced by ionizing radiation in many tumor cells. Recent findings revealed that quercetin inactivates protein chaperons by inhibiting the kinases which contribute to HSP induction [62]. Thus, quercetin may be applied as an adjuvant in combination with current chemotherapies in cancer treatment. Quercetin is also observed to arrest cell cycle in several types of cancers. Quercetin down-regulates cyclin D1/Cdk4 and E/ Cdk2 and up-regulates p21 and thereby induces the G1 cell cycle arrest [63]. Similarly, in vitro studies have reported that quercetin induces cell cycle arrest in $G 2 / M$, G0/G1 and G2/M phases [20, 21]. Moreover, quercetin arrests cell cycle in the $S$ phase by inhibiting DNA synthesis [64]. Quercetin-induced up-regulation of p21, p27, p53 and Chk2 along with down-regulation of Cdk1 and cyclin B1 leading to cell cycle arrest in the G1 and G2/m phase, have been observed in various cancer cell lines $[65,66]$.

Quercetin is able to directly bind tubulin by which induce depolymerization of cellular microtubules leading to cell cycle arrest [67]. Thus, quercetin affects a wide variety of molecules involved in the cell cycle process. PI3K-Akt/PKB pathway which is involved in several processes such as cell survival regulation, cell cycle and growth progression, and also carcinogenesis [68], can be 
targeted by quercetin in various types of cancers resulting in apoptosis induction and inhibition of cancer initiation and development [69]. Furthermore, tyrosine kinases are a kind of cancer-related molecules which play role in the transduction of growth factors and oncogenes. Recent findings revealed that quercetin inhibits tyrosine kinases leading to inhibition of the growth of tumor cells [70, 71]. Besides, p53 is a key molecule in the anti-cancer and pro-apoptotic effects of quercetin. Several studies have reported that quercetin induced phosphorylation and stabilizing of p53 levels. For instance, in HepG2 cells quercetin contributed to p53 expression and phosphorylation leading to cell cycle arrest and apoptosis induction [72]. Moreover, in colon carcinoma cells, quercetin and p53 contribution also resulted in increased expression of NAG-1 and thereby increased apoptosis [73]. Also, P53 increases p21 levels attenuating the pro-apoptotic effects of quercetin in cancer cells. On the other hand, p53 has antioxidant function by regulating of several genes, including microsomal GSH transferase homolog PIG12, Gpx1, aldehyde dehydrogenase ALDH4A1, Mn-SOD2, and catalase [74-76]. In oxidative stress condition, p53 is essential for decreasing intracellular ROS concentrations. Additionally, decreased p53 sensitizes cells to damage of $\mathrm{H} 2 \mathrm{O} 2$ which leads to decreased viability, increased apoptosis and elevated DNA oxidation. However, in cancer cells p53 functions are significantly blocked by down-regulating of its gene. So quercetin may improve ROS elevation induced by p53 deficiency through elevating of its levels [77]. Taken together, these findings highlight the significant effects of quercetin in cancer treatment. Apoptosis induction, pro-oxidant and antioxidant actions, cell cycle arrest induction, regulation of several cancers related proteins such as p53, HSPs, and tyrosine kinases are some mechanisms recently reported by which quercetin can inhibit cancers.

\section{Quercetin and ovarian cancer}

Recently, the effects of quercetin on ovarian cancer have been interesting for many researchers. In this way, several experimental studies have been conducted to elucidate the mechanisms by which quercetin inhibits ovarian cancer. Liu Y et al. [78] investigated the effect of quercetin on apoptosis in mice with ovarian cancer. The results showed that quercetin induced apoptosis via the mitochondria intrinsic and caspase-dependent pathways. Besides, quercetin evoked endoplasmic reticulum (ER) stress in ovarian cancer resulting in mitochondriamediated apoptosis. Furthermore, quercetin was able to induce autophagy which has a protective role in ovarian cancer cells. Taken together, this study indicated that quercetin induced ER stress, apoptosis and authophagy via a $\mathrm{p}-\mathrm{STAT} 3 / \mathrm{Bcl}-2$ axis. Another investigation reported that quercetin decreases the viability and induces apoptosis of metastatic ovarian cancer cells. Quercetin decreases several anti-apoptotic molecules, including Bcl-2 and Bcl-xL and increases pro-apoptotic molecules, including caspase-3, caspase-9, Bid, Bax, Bad and cytochrome c. In addition, quercetin inhibits the growth of metastatic ovarian cancer cells by the induction of mitochondrial-mediated apoptosis [79]. In a recent study, anti-cancer effects of nano-formulation of quercetin were examined. This form of quercetin significantly inhibited growth of ovarian cancer cells both in vitro and in xenograft ovarian cancer mice. Furthermore, nano-formulated quercetin induced apoptosis by activating caspase-3, caspase- 9 and Bax as well as reducing MCL-1 and Bcl-2 [80].

Several experiments have examined the synergistic effect of quercetin in combination with other chemotherapeutic agents against ovarian cancer. Gong c et al. [81] assessed the effect of quercetin in combination with irradiation on ovarian cancer in an in vitro/in vivo study. Quercetin treatment led to ER stress, increased expression of p53, p21 and Bax, decreased expression of Bcl-2, prolonged DNA repair as well as induced radiosensitization in ovarian cancer cells. In human ovarian cancer xenograft model, quercetin in combination with radiation significantly inhibited tumor growth and activated p53. In another recent report, quercetin pretreatment strongly potentiated cisplatin cytotoxicity in ovarian cancer. Quercetin increased ER stress, inhibited STAT3 phophphorylation, downregulated Bcl-2 expression in ovarian cancer cells. In xenograft mous model of ovarian cancer, quercetin also increased anti-tumor effects of cisplatin. In mice treated with cisplatin in combination with pretreatment of quercetin, lowered Bcl-2 and higher apoptosis were observed compared with other groups. This study suggested that quercetin may be a good candidate for adjuvant therapy in ovarian cancer treatment [82]. Another form of quercetin, PEGylated liposomal quercetin (Lipo-quercetin) was evaluated on cicplatin-sensitive and cisplatin-resistant human ovarian cancer models both in vitro and in vivo. In vitro investigations reported that Lipo-quercetin suppressed cell growth and induced apoptosis and cell cycle arrest in both tumor cell types. Experiments in ovarian cancer xenograft models of mice showed that Lipo-quercetin more inhibited tumor proliferation compared with free quercetin. Moreover, Lipo-quercetin induced apoptosis in in vivo study [83]. Likewise, another in vitro study supported the synergistic effect of quercetin in combination with cisplatin in ovarian cancer cells [84]. Some studies have investigated the influences of quercetin on cell cycle progression. The cell cycle modulation and cytotoxic effect of quercetin on ovarian cancer cells was investigated in an in vitro study. Findings showed that 
Table 1 Experimental studies that investigated the role of quercetin in ovarian cancer

\begin{tabular}{|c|c|c|c|c|c|}
\hline Form of quercetin & Doses & Type of cervical cancer & Model & Findings & Ref \\
\hline Quercerin & $80 \mathrm{mg} / \mathrm{kg}$ twice a week & - & In vivo & $\begin{array}{l}\text { Induced apoptosis, induced ER stress, } \\
\text { activated p-STAT3/ Bcl2 axis, induced } \\
\text { protective authophagy, }\end{array}$ & [78] \\
\hline 34'7TMQ & - & $\begin{array}{l}\text { Epithelial and fibroblast ovarian } \\
\text { cancer cell lines }\end{array}$ & In vitro & $\begin{array}{l}\text { Inhibited cell migration and invasion, } \\
\text { inhibited expression of UPA and } \\
\text { MMP-2 }\end{array}$ & [90] \\
\hline Quercetin & A dose range & Metastatic ovarian cancer cell line & In vitro & $\begin{array}{l}\text { Decreased viability, induced apoptosis, } \\
\text { decreased Bcl-2 and Bcl-xL, increased } \\
\text { caspase- } 3 \text {, caspase-p, Bid, Bad, Bax, } \\
\text { cytochrome c }\end{array}$ & [79] \\
\hline Quercetin & $100 \mu \mathrm{M}$ & $\begin{array}{l}\text { Multi-drug resistant ovarian cancer } \\
\text { cell line }\end{array}$ & In vitro & $\begin{array}{l}\text { Increased ER stress, prolonged DNA } \\
\text { repair, increased expression of p53, } \\
\text { p21 and Bax, decreased expression } \\
\text { of Bcl-2, induced radio-sensitization, }\end{array}$ & [81] \\
\hline Quercetin & - & $\begin{array}{l}\text { Human ovarian cancer xenograft } \\
\text { model }\end{array}$ & In vivo & $\begin{array}{l}\text { increased radiation-induced cell death, } \\
\text { increased p53, increased ER stress }\end{array}$ & \\
\hline \multirow[t]{2}{*}{ Quercetin } & A dose range & $\begin{array}{l}\text { Cisplatin sensitive and resistant } \\
\text { cell lines }\end{array}$ & In vitro & $\begin{array}{l}\text { Enhanced cisplatin cytotoxicity, increased } \\
\text { ER stress, suppressed STAT-3 } \\
\text { phosphorylation, decreased expression } \\
\text { of Bcl-2, }\end{array}$ & [82] \\
\hline & 40 mg/kg once a week & $\begin{array}{l}\text { Human ovarian cancer xenograft } \\
\text { model }\end{array}$ & In vivo & $\begin{array}{l}\text { Suppressed STAY-3 phosphorylation, } \\
\text { decreased Bcl-2 expression, induced } \\
\text { apoptosis }\end{array}$ & \\
\hline Quercetin & A dose range & $\begin{array}{l}\text { Epithelial ovarian cancer cell line } \\
\text { and its CIS-resistant cell line }\end{array}$ & In vitro & Decreased expression of cyclin D1 & [85] \\
\hline Quercetin & A dose range & Epithelial ovarian cancer cell line & In vitro & $\begin{array}{l}\text { Inhibited proliferation, induced } \\
\text { apoptosis, decreased survivin, induced } \\
\text { cell cycle arrest }\end{array}$ & [86] \\
\hline \multirow[t]{2}{*}{ Nano-formulation of quercetin } & A dose range & $\begin{array}{l}\text { Ovarian endometrioid } \\
\text { adenocarcinoma }\end{array}$ & In vitro & $\begin{array}{l}\text { Inhibited growth, induced apoptosis, } \\
\text { activated caspase-3 and caspase-9, } \\
\text { decreased expression of MCL-1 and } \\
\text { BCl-2, increased expression of Bax }\end{array}$ & [80] \\
\hline & A dose range & $\begin{array}{l}\text { Human ovarian cancer xenograft } \\
\text { model }\end{array}$ & In vivo & $\begin{array}{l}\text { Inhibited growth, induced apoptosis, } \\
\text { inhibited angiogenesis }\end{array}$ & \\
\hline \multirow[t]{2}{*}{ Quercetin } & A dose range & $\begin{array}{l}\text { Epithelial and drug resistant ovarian } \\
\text { cancer cell lines }\end{array}$ & In vitro & $\begin{array}{l}\text { Decreased ROS, increased anti-oxidant } \\
\text { enzymes, inhibited apoptosis }\end{array}$ & [91] \\
\hline & & $\begin{array}{l}\text { Human ovarian cancer xenograft } \\
\text { model }\end{array}$ & In vivo & $\begin{array}{l}\text { Increased anti-oxidant enzymes } \\
\text { expression, reduced ROS, decreased } \\
\text { anti-neoplastic drug's efficacy }\end{array}$ & \\
\hline \multirow[t]{2}{*}{ Lipo-Que } & - & $\begin{array}{l}\text { CIS-resistant and CIS-sensitive } \\
\text { ovarian cancer cell lines }\end{array}$ & In vitro & $\begin{array}{l}\text { Inhibited proliferation, induced } \\
\text { apoptosis, induced cell cycle arrest }\end{array}$ & [83] \\
\hline & & $\begin{array}{l}\text { Human ovarian cancer xenograft } \\
\text { model }\end{array}$ & In vivo & $\begin{array}{l}\text { Inhibited tumor growth, inhibited } \\
\text { proliferation, induced apoptosis }\end{array}$ & \\
\hline Quercetin & $2 \mathrm{mg} / \mathrm{kg}$ & $\begin{array}{l}\text { Human ovarian cancer xenograft } \\
\text { model }\end{array}$ & In vivo & $\begin{array}{l}\text { Increased TRAIL sensitization, inhibited } \\
\text { tumor growth, increased caspase-3, } \\
\text { induced apoptosis }\end{array}$ & {$[88]$} \\
\hline Quercetin & 10 microM & Ovarian serous adenocarcinoma & In vitro & Increased TGF beta 1 activity & [89] \\
\hline Quercetin & A dose range & $\begin{array}{l}\text { Metastatic ovarian serous } \\
\text { adenocarcinoma }\end{array}$ & In vitro & Inhibited PI kinase, decreased IP3 levels & {$[87]$} \\
\hline
\end{tabular}

quercetin decreased the expression of cycline D1 without influence on cyclin B1 which could be associated with $\mathrm{G} 1 / \mathrm{S}$ phase alteration [85]. In an experimental study, quercetin could inhibit proliferation and induce apoptosis in ovarian cancer cells in a dose manner. The protein levels of survivin were decreased when the quercetin dose increased. Quercetin also led to cell cycle arrest in G0/G1 phase and G2/M phase [86]. Another study revealed that quercetin may arrest the cell cycle via inhibiting 1-phosphatidylinositol 4-kinase (PI kinase) 


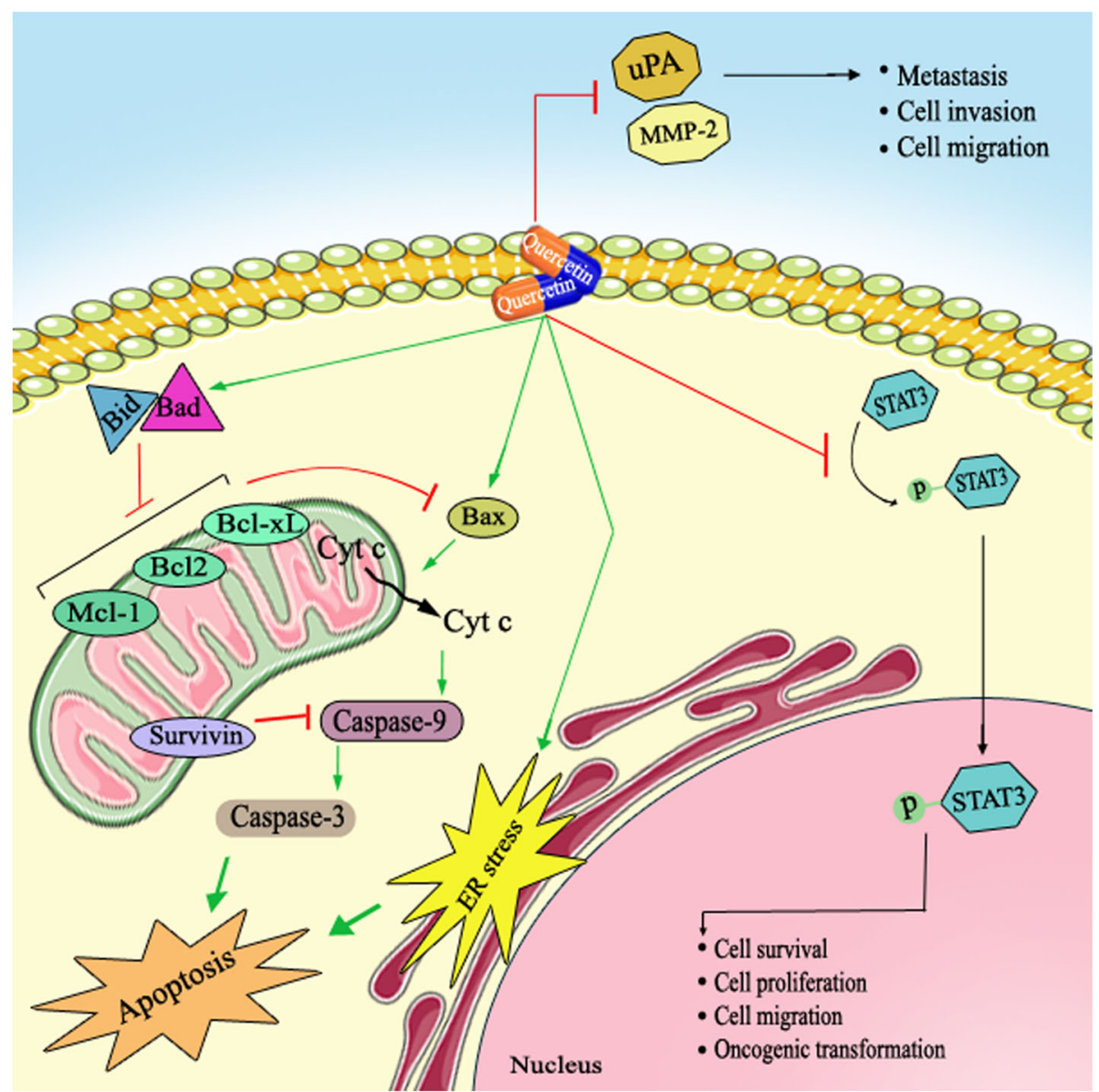

Fig. 1 Schematic representation in targeting different signaling pathways using quercetin as a novel therapeutic strategy in the treatment of ovarian cancer

activity and reducing inositol-1,4,5-triphosphate (IP3) levels [87]. Tumor necrosis factor-related apoptosisinducing ligand (TRAIL) has been proven to have antitumor activity in several cancer types including ovarian cancer. Yi L et al. [88] evaluated the effect of quercetin on sensitization of ovarian cancer cells to TRAIL. Results indicated that quercetin elevated the sensitization of tumor cells to TRAIL leading to reduced expression of cell survival proteins, inhibited tumor growth and increased pro-apoptotic proteins including caspase-3. Scambia et al. [89] demonstrated that quercetin inhibited growth of ovarian cancer cells via modulating transforming growth factor beta 1 (TGF-beta-1) production. Results indicate that quercetin increased TGF-beta-1 activity. Northern blot analysis revealed no alteration in TGF-beta-1 mRNA levels suggesting that TGF-beta-1 modulation occurs at posttranscriptional levels. In an in vitro study, the effect of methylquercetin, 3,4',7-O-trimethylquercetin (34'7TMQ) on proliferation, invasion and migration of ovarian cancer cells were measured. In mentioned study, the expression of proliferating cell nuclear antigen (PCNA) urokinase plasminogen activator (uPA), plasminogen activator inhibitor-1(PAI-1) and MMP-2 were analyzed. The results indicated that 34'7TMQ inhibited the migration and the invasion of ovarian cancer cells but had no effect on cell proliferation. After 34'7TMQ treatment, the expression of uPA and MMP-2 also inhibited, but PAI-1 and PCNA levels were not changed [90]. In contrast to above results which revealed the beneficial effects of quercetin in ovarian cancer treatment especially in combination with other treatments, a recent experimental study reported that quercetin lowered the effects of some antineoplastic drugs including cisplatin, 5-fluorouracil, taxol, and pirarubicin. Low concentrations of quercetin had anti-apoptotic effect and decreased ROSmediated injury of anti-neoplastic drugs and also increased antioxidant enzymes in tumor cells [91]. Taken together, these findings have demonstrated that quercetin exerts antitumor features against ovarian cancer via several mechanisms (Table 1). 


\section{Conclusions}

In etiology of ovarian cancer, several molecular mechanisms, including inflammation, oxidative stress and DNA damage are complicated. Findings reported that quercetin inhibits ovarian cancer by its anti-inflammatory, prooxidative, anti-proliferation, apoptosis induction, and cell cycle arrest induction activities. Besides, this natural compound can intensify the effects of other chemotherapeutic drugs (Table 1 and Fig. 1). However, more investigations are required to completely elucidate its exact mechanisms of action against ovarian cancer. Collectively, quercetin may be a good candidate for ovarian cancer treatment especially in combination with other chemopreventive drugs due to its potential synergistic effects.

\section{Abbreviations}

ECM: extracellular matrix; MMPs: matrix metalloproteinase; PDGF: plateletderived growth factor; TGF- $\beta$ : transforming growth factor- $\beta$; VEGF: vascular endothelial growth factor

\section{Acknowledgements}

Not applicable.

\section{Authors' contributions}

ZA contributed in conception, design and drafting of the manuscript. RS contributed in data collection and manuscript drafting. All authors approved the final version for submission. ZA oversaw the study.

\section{Funding}

The present study was founded by a grant from the Vice Chancellor for Research, Kashan University of Medical Sciences, in Iran.

\section{Availability of data and materials}

The primary data for this study is available from the authors on direct request.

\section{Ethics approval and consent to participate}

This study was considered exempt by the KAUMS Institutional Review Board.

\section{Consent for publication}

Not applicable.

\section{Competing interests}

The authors declare that they have no competing interests.

Received: 17 April 2019 Accepted: 4 June 2019

Published online: 15 June 2019

\section{References}

1. Henderson JT, Webber EM, Sawaya GF. Screening for ovarian Cancer: updated evidence report and systematic review for the us preventive services task force. JAMA. 2018;319:595-606.

2. Jayson GC, Kohn EC, Kitchener HC, Ledermann JA. Ovarian cancer. Lancet. 2014:384:1376-88.

3. Stewart C, Ralyea C, Lockwood S. Ovarian cancer: an integrated review. Semin Oncol Nurs. 2019;35:151-6.

4. Nik NN, Vang R, Shih le M, Kurman RJ. Origin and pathogenesis of pelvic (ovarian, tubal, and primary peritoneal) serous carcinoma. Annu Rev Pathol. 2014:9:27-45.

5. Chien J, Poole EM. Ovarian cancer prevention, screening, and early detection: report from the 11th biennial ovarian cancer research symposium. Int J Gynecol Cancer. 2017;27:S20-s2.

6. Seidman JD, Kurman RJ. Pathology of ovarian carcinoma. Hematol Oncol Clin North Am. 2003;17:909-25.

7. Rais J, Jafri A, Siddiqui S, Tripathi M, Arshad M. Phytochemicals in the treatment of ovarian cancer. Front Biosci (Elite Ed). 2017;9:67-75.
8. Ventura A, Kirsch DG, McLaughlin ME, Tuveson DA, Grimm J, Lintault L, et al Restoration of p53 function leads to tumour regression in vivo. Nature. 2007:445:661-5.

9. Thomasset SC, Berry DP, Garcea G, Marczylo T, Steward WP, Gescher AJ. Dietary polyphenolic phytochemicals--promising cancer chemopreventive agents in humans? A review of their clinical properties. Int J Cancer. 2007; 120:451-8.

10. Metodiewa D, Jaiswal AK, Cenas N, Dickancaite E, Segura-Aguilar J. Quercetin may act as a cytotoxic prooxidant after its metabolic activation to semiquinone and quinoidal product. Free Radic Biol Med. 1999;26:107-16.

11. Harwood M, Danielewska-Nikiel B, Borzelleca JF, Flamm GW, Williams GM, Lines TC. A critical review of the data related to the safety of quercetin and lack of evidence of in vivo toxicity, including lack of genotoxic/carcinogenic properties. Food Chem Toxicol. 2007;45:2179-205.

12. Bischoff SC. Quercetin: potentials in the prevention and therapy of disease. Curr Opin Clin Nutr Metab Care. 2008;11:733-40.

13. Boots AW, Haenen GR, Bast A. Health effects of quercetin: from antioxidant to nutraceutical. Eur J Pharmacol. 2008;585:325-37.

14. Hirpara KV, Aggarwal P, Mukherjee AJ, Joshi N, Burman AC. Quercetin and its derivatives: synthesis, pharmacological uses with special emphasis on anti-tumor properties and prodrug with enhanced bio-availability. Anti Cancer Agents Med Chem. 2009;9:138-61.

15. D'Andrea G. Quercetin: a flavonol with multifaceted therapeutic applications? Fitoterapia. 2015;106:256-71.

16. Panche AN, Diwan AD, Chandra SR. Flavonoids: an overview. J Nutr Sci. 2016;5:e47.

17. Song NR, Chung MY, Kang NJ, Seo SG, Jang TS, Lee HJ, et al. Quercetin suppresses invasion and migration of H-Ras-transformed MCF10A human epithelial cells by inhibiting phosphatidylinositol 3-kinase. Food Chem. 2014; 142:66-71.

18. Gates MA, Vitonis AF, Tworoger SS, Rosner B, Titus-Ernstoff L, Hankinson SE, et al. Flavonoid intake and ovarian cancer risk in a population-based casecontrol study. Int J Cancer. 2009;124:1918-25.

19. Choi JA, Kim JY, Lee JY, Kang CM, Kwon HJ, Yoo YD, et al. Induction of cell cycle arrest and apoptosis in human breast cancer cells by quercetin. Int J Oncol. 2001;19:837-44

20. Kuo PC, Liu HF, Chao Jl. Survivin and p53 modulate quercetin-induced cell growth inhibition and apoptosis in human lung carcinoma cells. J Bio Chem. 2004;279:55875-85.

21. Ong CS, Tran E, Nguyen TT, Ong CK, Lee SK, Lee JJ, et al. Quercetin-induced growth inhibition and cell death in nasopharyngeal carcinoma cells are associated with increase in bad and hypophosphorylated retinoblastoma expressions. Oncol Rep. 2004;11:727-33.

22. Sharmila G, Bhat FA, Arunkumar R, Elumalai P, Raja Singh P, Senthilkumar K, et al. Chemopreventive effect of quercetin, a natural dietary flavonoid on prostate cancer in in vivo model. Clin Nutr. 2014;33:718-26.

23. Gates MA, Tworoger SS, Hecht JL, De Vivo I, Rosner B, Hankinson SE. A prospective study of dietary flavonoid intake and incidence of epithelial ovarian cancer. Int J Cancer. 2007;121:2225-32

24. Larsson SC, Holmberg L, Wolk A. Fruit and vegetable consumption in relation to ovarian cancer incidence: the Swedish mammography cohort. Brit J Cancer. 2004;90:2167-70.

25. Schulz M, Lahmann PH, Boeing H, Hoffmann K, Allen N, Key TJ, et al. Fruit and vegetable consumption and risk of epithelial ovarian cancer: the European prospective investigation into Cancer and nutrition. Cancer Epidemiol Biomark Prev. 2005;14:2531-5.

26. Cassidy A, Huang T, Rice MS, Rimm EB, Tworoger SS. Intake of dietary flavonoids and risk of epithelial ovarian cancer. Am J Clin Nutr. 2014;100 1344-51.

27. Vargas AJ, Burd R. Hormesis and synergy: pathways and mechanisms of quercetin in cancer prevention and management. Nutr Rev. 2010;68:418-28.

28. Fathalla MF. Incessant ovulation--a factor in ovarian neoplasia? Lancet. 1971; 2:163.

29. Godwin AK, Testa JR, Handel LM, Liu Z, Vanderveer LA, Tracey PA, et al. Spontaneous transformation of rat ovarian surface epithelial cells: association with cytogenetic changes and implications of repeated ovulation in the etiology of ovarian cancer. J Natl Cancer Inst. 1992;84:592-601.

30. Saed GM, Diamond MP, Fletcher NM. Updates of the role of oxidative stress in the pathogenesis of ovarian cancer. Gynecol Oncol. 2017;145:595-602.

31. Cramer DW, Welch WR. Determinants of ovarian cancer risk. II. Inferences regarding pathogenesis. J Natl Cancer Inst. 1983;71:717-21. 
32. Risch HA. Hormonal etiology of epithelial ovarian cancer, with a hypothesis concerning the role of androgens and progesterone. J Natl Cancer Inst. 1998;90:1774-86

33. Ness RB, Cottreau C. Possible role of ovarian epithelial inflammation in ovarian cancer. J Natl Cancer Inst. 1999;91:1459-67.

34. Kang YC, Kim KM, Lee KS, Namkoong S, Lee SJ, Han JA, et al. Serum bioactive lysophospholipids prevent TRAIL-induced apoptosis via PI3K/Aktdependent CFLIP expression and bad phosphorylation. Cell Death Differ. 2004;11:1287-98.

35. Giuntoli RL, 2nd, Webb TJ, Zoso A, Rogers O, Diaz-Montes TP, Bristow RE, et al. Ovarian cancer-associated ascites demonstrates altered immune environment: implications for antitumor immunity. Anticancer Res 2009;29: 2875-2884.

36. Bast RC, Jr., Hennessy B, Mills GB. The biology of ovarian cancer: new opportunities for translation. Nat Rev Cancer 2009;9:415-428.

37. Chou CH, Wei LH, Kuo ML, Huang YJ, Lai KP, Chen CA, et al. Up-regulation of interleukin-6 in human ovarian cancer cell via a Gi/PI3K-Akt/NF-kappaB pathway by lysophosphatidic acid, an ovarian cancer-activating factor. Carcinogenesis. 2005;26:45-52.

38. Mackay HJ, Twelves CJ. Targeting the protein kinase C family: are we there yet? Nature Rev Cancer. 2007;7:554-62.

39. Dreher D, Junod AF. Role of oxygen free radicals in cancer development. Eur J Cancer. 1996;32a:30-8.

40. Ames BN, Gold LS, Willett WC. The causes and prevention of cancer. Proc Natl Acad Sci U S A. 1995;92:5258-65.

41. Auersperg N, Edelson MI, Mok SC, Johnson SW, Hamilton TC. The biology of ovarian cancer. Semin Oncol. 1998;25:281-304.

42. Aitokallio-Tallberg AM, Viinikka LU, Ylikorkala RO. Increased synthesis of prostacyclin and thromboxane in human ovarian malignancy. Cancer Res. 1988:48:2396-8.

43. Subbaramaiah K, Zakim D, Weksler BB, Dannenberg AJ. Inhibition of cyclooxygenase: a novel approach to cancer prevention. Proc Soc Exp Biol Med. 1997;216:201-10.

44. Senthil K, Aranganathan S, Nalini N. Evidence of oxidative stress in the circulation of ovarian cancer patients. Clin Chim Acta. 2004;339:27-32.

45. Saed GM, Ali-Fehmi R, Jiang ZL, Fletcher NM, Diamond MP, Abu-Soud HM, et al. Myeloperoxidase serves as a redox switch that regulates apoptosis in epithelial ovarian cancer. Gynecol Oncol. 2010;116:276-81.

46. Saed GM, Fletcher NM, Jiang ZL, Abu-Soud HM, Diamond MP

Dichloroacetate induces apoptosis of epithelial ovarian cancer cells through a mechanism involving modulation of oxidative stress. Reprod Sci. 2011;18: 1253-61.

47. Fletcher NM, Jiang Z, Ali-Fehmi R, Levin NK, Belotte J, Tainsky MA, et al. Myeloperoxidase and free iron levels: potential biomarkers for early detection and prognosis of ovarian cancer. Cancer Biomark. 2011;10:267-75.

48. Jiang Z, Fletcher NM, Ali-Fehmi R, Diamond MP, Abu-Soud HM, Munkarah $A R$, et al. Modulation of redox signaling promotes apoptosis in epithelial ovarian cancer cells. Gynecol Oncol. 2011;122:418-23.

49. Malone JM, Saed GM, Diamond MP, Sokol RJ, Munkarah AR. The effects of the inhibition of inducible nitric oxide synthase on angiogenesis of epithelial ovarian cancer. Am J Obstet Gynecol. 2006;194:1110-6.

50. Abu-Soud HM, Hazen SL. Nitric oxide is a physiological substrate for mammalian peroxidases. J Biol Chem. 2000;275:37524-32.

51. Abu-Soud HM, Hazen SL. Nitric oxide modulates the catalytic activity of myeloperoxidase. J Biol Chem. 2000:275:5425-30.

52. Castillo-Tong DC, Pils D, Heinze G, Braicu I, Sehouli J, Reinthaller A, et al. Association of myeloperoxidase with ovarian cancer. Tumour Biol. 2014;35:141-8.

53. Watjen W, Michels G, Steffan B, Niering P, Chovolou Y, Kampkotter A, et al. Low concentrations of flavonoids are protective in rat H4IIE cells whereas high concentrations cause DNA damage and apoptosis. J Nutr. 2005;135:525-31.

54. Awad HM, Boersma MG, Vervoort J, Rietjens IM. Peroxidase-catalyzed formation of quercetin quinone methide-glutathione adducts. Arch Biochem Biophys. 2000;378:224-33.

55. Egert S, Wolffram S, Bosy-Westphal A, Boesch-Saadatmandi C, Wagner AE, Frank J, et al. Daily quercetin supplementation dose-dependently increases plasma quercetin concentrations in healthy humans. J Nutr. 2008;138:1615-21.

56. Tan J, Wang B, Zhu L. Regulation of survivin and BCl-2 in HepG2 cell apoptosis induced by quercetin. Chem Biodivers. 2009;6:1101-10.

57. Zhang Q, Zhao XH, Wang ZJ. Flavones and flavonols exert cytotoxic effects on a human oesophageal adenocarcinoma cell line (OE33) by causing G2/ $\mathrm{M}$ arrest and inducing apoptosis. Food Chem Toxicol. 2008;46:2042-53.
58. Zhang Q, Zhao XH, Wang ZJ. Cytotoxicity of flavones and flavonols to a human esophageal squamous cell carcinoma cell line (KYSE-510) by induction of G2/M arrest and apoptosis. Toxicol in Vitro. 2009;23:797-807.

59. Roos WP, Kaina B. DNA damage-induced cell death by apoptosis. Trends Mol Med. 2006;12:440-50.

60. Siegelin MD, Reuss DE, Habel A, Rami A, von Deimling A. Quercetin promotes degradation of survivin and thereby enhances death-receptormediated apoptosis in glioma cells. Neuro-Oncology. 2009;11:122-31.

61. Aalinkeel R, Bindukumar B, Reynolds JL, Sykes DE, Mahajan SD, Chadha KC, et al. The dietary bioflavonoid, quercetin, selectively induces apoptosis of prostate cancer cells by down-regulating the expression of heat shock protein 90. Prostate. 2008;68:1773-89.

62. Wang RE, Kao JL, Hilliard CA, Pandita RK, Roti Roti JL, Hunt CR, et al. Inhibition of heat shock induction of heat shock protein 70 and enhancement of heat shock protein 27 phosphorylation by quercetin derivatives. J Med Chem. 2009;52:1912-21.

63. Moon SK, Cho GO, Jung SY, Gal SW, Kwon TK, Lee YC, et al. Quercetin exerts multiple inhibitory effects on vascular smooth muscle cells: role of ERK1/2, cell-cycle regulation, and matrix metalloproteinase-9. Biochem Biophys Res Commun. 2003;301:1069-78.

64. Haghiac M, Walle T. Quercetin induces necrosis and apoptosis in SCC-9 oral cancer cells. Nutr Cancer. 2005;53:220-31.

65. Mu C, Jia P, Yan Z, Liu X, Li X, Liu H. Quercetin induces cell cycle G1 arrest through elevating Cdk inhibitors p21 and p27 in human hepatoma cell line (HepG2). Methods Find Exp Clin Pharmacol. 2007;29:179-83.

66. Jeong JH, An JY, Kwon YT, Rhee JG, Lee YJ. Effects of low dose quercetin: cancer cell-specific inhibition of cell cycle progression. J Cell Biochem. 2009; 106:73-82.

67. Gupta K, Panda D. Perturbation of microtubule polymerization by quercetin through tubulin binding: a novel mechanism of its antiproliferative activity. Biochemistry. 2002;41:13029-38.

68. Fresno Vara JA, Casado E, de Castro J, Cejas P, Belda-Iniesta C, GonzalezBaron M. PI3K/Akt signalling pathway and cancer. Cancer Treat Rev. 2004;30: 193-204.

69. Gulati N, Laudet B, Zohrabian VM, Murali R, Jhanwar-Uniyal M. The antiproliferative effect of quercetin in cancer cells is mediated via inhibition of the PI3K-Akt/PKB pathway. Anticancer Res. 2006;26:1177-81.

70. Boutin JA. Tyrosine protein kinase inhibition and cancer. Int J BioChemiPhysics. 1994;26:1203-26.

71. Ferry DR, Smith A, Malkhandi J, Fyfe DW, deTakats PG, Anderson D, et al. Phase I clinical trial of the flavonoid quercetin: pharmacokinetics and evidence for in vivo tyrosine kinase inhibition. Clin Cancer Res. 1996;2:659-68.

72. Tanigawa S, Fujii M, Hou DX. Stabilization of p53 is involved in quercetininduced cell cycle arrest and apoptosis in HepG2 cells. Biosci Biotechnol Biochem. 2008:72:797-804

73. Lim JH, Park JW, Min DS, Chang JS, Lee YH, Park YB, et al. NAG-1 upregulation mediated by EGR-1 and p53 is critical for quercetin-induced apoptosis in HCT116 colon carcinoma cells. Apoptosis. 2007;12:411-21.

74. Polyak K, Xia Y, Zweier JL, Kinzler KW, Vogelstein B. A model for p53induced apoptosis. Nature. 1997;389:300-5.

75. Yoon KA, Nakamura Y, Arakawa H. Identification of ALDH4 as a p53inducible gene and its protective role in cellular stresses. J Hum Genet. 2004:49:134-40.

76. Hussain SP, Amstad P, He P, Robles A, Lupold S, Kaneko I, et al. p53-induced up-regulation of MnSOD and GPx but not catalase increases oxidative stress and apoptosis. Cancer Res. 2004;64:2350-6.

77. Gibellini L, Pinti M, Nasi M, Montagna JP, De Biasi S, Roat E, et al. Quercetin and cancer chemoprevention. Evid Based Complement Alternat Med. 2011; 2011:591356.

78. Liu Y, Gong W, Yang ZY, Zhou XS, Gong C, Zhang TR, et al. Quercetin induces protective autophagy and apoptosis through ER stress via the $p$ STAT3/BCl-2 axis in ovarian cancer. Apoptosis. 2017;22:544-57.

79. Teekaraman D, Elayapillai SP, Viswanathan MP, Jagadeesan A. Quercetin inhibits human metastatic ovarian cancer cell growth and modulates components of the intrinsic apoptotic pathway in PA-1cell line. Chem Biol Interact. 2019;300:91-100.

80. Gao X, Wang B, Wei X, Men K, Zheng F, Zhou Y, et al. Anticancer effect and mechanism of polymer micelle-encapsulated quercetin on ovarian cancer. Nanoscale. 2012:4:7021-30.

81. Gong C, Yang Z, Zhang L, Wang Y, Gong W, Liu Y. Quercetin suppresses DNA double-strand break repair and enhances the radiosensitivity of 
human ovarian cancer cells via p53-dependent endoplasmic reticulum stress pathway. Onco Targets Ther. 2018;11:17-27.

82. Yang Z, Liu Y, Liao J, Gong C, Sun C, Zhou X, et al. Quercetin induces endoplasmic reticulum stress to enhance CDDP cytotoxicity in ovarian cancer: involvement of STAT3 signaling. FEBS J. 2015;282:1111-25.

83. Long $Q$, Xiel $Y$, Huang $Y$, Wu Q, Zhang $H$, Xiong $S$, et al. Induction of apoptosis and inhibition of angiogenesis by PEGylated liposomal quercetin in both cisplatin-sensitive and cisplatin-resistant ovarian cancers. J Biomed Nanotechnol. 2013;9:965-75.

84. Scambia G, Ranelletti FO, Benedetti Panici P, Bonanno G, De Vincenzo R, Piantelli $M$, et al. Synergistic antiproliferative activity of quercetin and cisplatin on ovarian cancer cell growth. Anti-Cancer Drugs. 1990;1:45-8.

85. Catanzaro D, Ragazzi E, Vianello C, Caparrotta L, Montopoli M. Effect of quercetin on cell cycle and cyclin expression in ovarian carcinoma and osteosarcoma cell lines. Nat Prod Commun. 2015;10:1365-8.

86. Ren MX, Deng XH, Ai F, Yuan GY, Song HY. Effect of quercetin on the proliferation of the human ovarian cancer cell line SKOV-3 in vitro. Exp Ther Med. 2015;10:579-83.

87. Shen F, Herenyiova M, Weber G. Synergistic down-regulation of signal transduction and cytotoxicity by tiazofurin and quercetin in human ovarian carcinoma cells. Life Sci. 1999;64:1869-76.

88. Yi L, Zongyuan Y, Cheng G, Lingyun Z, Guilian Y, Wei G. Quercetin enhances apoptotic effect of tumor necrosis factor-related apoptosis-inducing ligand (TRAlL) in ovarian cancer cells through reactive oxygen species (ROS) mediated CCAAT enhancer-binding protein homologous protein (CHOP)death receptor 5 pathway. Cancer Sci. 2014;105:520-7.

89. Scambia G, Panici PB, Ranelletti FO, Ferrandina G, De Vincenzo R, Piantelli M, et al. Quercetin enhances transforming growth factor beta 1 secretion by human ovarian cancer cells. Int J Cancer. 1994;57:211-5.

90. Yamauchi K, Afroze SH, Mitsunaga T, McCormick TC, Kuehl TJ, Zawieja DC, et al. 3,4,7-O-trimethylquercetin inhibits invasion and migration of ovarian Cancer cells. Anticancer Res. 2017;37:2823-9.

91. Li N, Sun C, Zhou B, Xing H, Ma D, Chen G, et al. Low concentration of quercetin antagonizes the cytotoxic effects of anti-neoplastic drugs in ovarian cancer. PLoS One. 2014;9:e100314. https://doi.org/10.1371/journal. pone.0100314

\section{Publisher's Note}

Springer Nature remains neutral with regard to jurisdictional claims in published maps and institutional affiliations.

Ready to submit your research? Choose BMC and benefit from:

- fast, convenient online submission

- thorough peer review by experienced researchers in your field

- rapid publication on acceptance

- support for research data, including large and complex data types

- gold Open Access which fosters wider collaboration and increased citations

- maximum visibility for your research: over $100 \mathrm{M}$ website views per year

At BMC, research is always in progress.

Learn more biomedcentral.com/submissions 